\title{
Sexual reproduction in freshwater fairy shrimp, Dendrocephalus brasiliensis (Pesta, 1921) inferred by Amplified Fragment Length Polymorphism markers
}

Reprodução sexual do microcrustáceo de água doce, Dendrocephalus brasiliensis (Pesta, 1921), deduzida a partir de marcadores de Polimorfismo de Comprimento de Fragmento Amplificado

\author{
Suzianny Maria Bezerra Cabral da Silva ${ }^{I}$ Leilane Bruna Gomes dos Santos ${ }^{I}$ \\ José Patrocínio Lopes ${ }^{I I}$ Alfredo Olivera Gálvez ${ }^{I}$ Maria Raquel Moura Coimbra ${ }^{{ }^{*}}$
}

\section{ABSTRACT}

Fluctuations in world harvests of Artemia sp cysts have increased prices sharply in the past years. Several organisms have been tested as alternative sources for a total or partial replacement of Artemia sp, among which the microcrustacean (Anostraca) Dendrocephalus brasiliensis stands out. The objective of this study was to investigate the reproductive strategy of $\boldsymbol{D}$. brasiliensis by means of AFLP markers. The distinction between sexual and parthenogenetic reproduction was conducted using 7 EcoRI and MseI primer combinations in a full-sib family composed of 13 progenies. Forty polymorphic markers were obtained, of these, $35 \%$ were from paternal origin and $65 \%$ were maternally inherited. Results showed mendelian segregation in all markers through the chi-square at $P \leq 0.05$. Sex changes were observed after 72 hours of grouping individuals of the same sex in a container, suggesting a possible sex density-dependent behavior. Paternal inheritance revealed that this species adopts sexual reproduction under experimental conditions.

Key words: Microcrustacea, AFLP, Paternal inheritance, Sexual reproduction.

\section{RESUMO}

Há vários anos que a produção de cistos de Artemia sp. apresenta flutuações, o que aumenta consideravelmente o seu valor. Vários organismos têm sido testados para a substituição total ou parcial da Artemia, dentre os quais se destaca o microcrustáceo (Anostraca) Dendrocephalus brasiliensis. O objetivo do presente trabalho foi investigar a estratégia reprodutiva de D. brasiliensis por meio de marcadores de AFLP. A distinção entre uma reprodução sexuada e partenogenética foi feita a partir da genotipagem de sete combinações de primers de AFLP em uma familia composta de 13 progênies. Quarenta marcadores polimórficos foram obtidos, dos quais $35 \%$ foram de origem paterna e $65 \%$, materna. Os resultados mostraram a segregação mendeliana de todos os marcadores através do teste de qui-quadrado a $P \leq 0.05$. Mudanças de sexo foram observadas após 72 horas do agrupamento de individuos de mesmo sexo em um recipiente, sugerindo uma possivel razão sexual populacional densidade-dependente. A herança paterna mostrou que a reprodução sexual é adotada por essa espécie sob condições experimentais.

Palavras-chave: microcrustáceo, AFLP, herança paterna, reprodução sexual.

\section{INTRODUCTION}

Aquaculture production plays a substantial role in global supplies of fish and fishery products, with a total production of 68.3 million tonnes in 2008 (FAO, 2010). In Brazil, aquaculture production has expanded considerably over the past decade, maintaining an annual growth rate of around $20 \%$, with a total production of 271,695 tonnes in 2006 (IBAMA, 2008). Though, the larval nutrition of aquatic animals has proven to be a major obstacle to aquaculture development, for species such as salmon, the presence of a large yolk sac ensures the development of a digestive system able to accept formulated feeds. However, most viable species for marine aquaculture have a small yolk sac at hatching and a primitive digestive system, which limits survival (SORGELOOS et al., 1991).

With the development of commercial hatcheries in the 1990s, the use of Artemia sp. as a live diet for the larvae of many species has increased worldwide (LAVENS \& SORGELOOS, 2000).

\footnotetext{
IDepartamento de Pesca e Aquicultura, Universidade Federal Rural de Pernambuco (UFRPE.), Rua Dom Manoel de Medeiros, s/n, 52171-900, Dois Irmãos, Recife, PE, Brasil. E-mail: raquel@depaq.ufrpe.br. *Autor para correspondência.

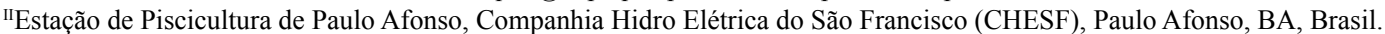


However, the availability and high cost of Artemia cysts due to periodic fluctuations in supply have contributed to a lack of predictability with regard to production costs (D'ABRAMO et al., 2006). The cladoceran Moina sp. (ALAM et al., 1991; MARTÍN et al., 2006) and rotifer Brachionus plicatilis (LOVETT \& FELDER, 1988) have been tested as replacements for Artemia sp. in the postlarval production of the species Macrobrachium rosenbergii and Litopenaeus schmitti. Another potential substitute is the microcrustacean (Anostraca) Dendrocephalus brasiliensis as a living or inert food in hatcheries for freshwater carnivorous fingerlings as well as the post-larvae of Litopenaeus vannamei (YFLAAR \& OLIVERA, 2003).

D. brasiliensis displays sexual dimorphism. Females are identified by the brood pouch near the tail and flat, round-ended antennae, while males have a vertical appendix and spineless eyes (COHEN, 1995; RABET \& THIÉRY, 1996). However, little is known regarding reproduction of the species beyond an indication of sexual reproduction suggested by COHEN (1995).

Molecular markers have proven to be of considerable usefulness in the investigation of genetic inheritance patterns. The PCR-based fingerprinting technique of Amplified Fragment Length Polymorphism (AFLP) is based on the detection of genomic restriction fragments without prior sequence information using a limited set of generic primers, resulting in large numbers of markers per reaction (VOS et al., 1995). AFLP have been used in Artemia for describing genetic diversity (TRIANTAPHYLLIDIS et al., 1997; SUN et al., 1999). In the present study, the occurrence of sexual reproduction in $\boldsymbol{D}$. brasiliensis was investigated in a full-sib family by AFLP markers.

\section{MATERIALS AND METHODS}

D. brasiliensis cysts were obtained from the Paulo Afonso Fish Aquaculture Station (09²2'38"S and $\left.38^{\circ} 13^{\prime} 58^{\prime \prime} \mathrm{W}\right)$ in northeast Brazil. The cysts were maintained in a $1-\mathrm{L}$ hatching container at $25^{\circ} \mathrm{C}$ for $24 \mathrm{~h}$. Sixteen pairs (A to P) were isolated soon after hatching in order to ensure at least one male and female pair. The specimens were transferred to a 1-L nylon screen container and maintained for a period of 30 days at approximately $27^{\circ} \mathrm{C}$ in a fertilised pond measuring $50 \mathrm{~m}^{2}$ and a mean depth of $0.80 \mathrm{~m}$. As the specimens displayed sexual dimorphism, they were placed in new 1-L nylon screen containers for effective mating and breeding under the same culture conditions. A single pair generated progenies and tissue from the entire family was collected for DNA extraction.

As only one pair generated progenies, a second experiment was carried out indoors with 20 additional pairs of nauplii (A' to T') maintained in 30$\mathrm{mL}$ glass recipients containing distilled water with a daily renewal rate of $10 \%$ and fed on the microalgae Chlorella sp. at a concentration of 30,000 cells $\mathrm{mL}^{-1}$ day $^{-1}$. The water was maintained at $28^{\circ} \mathrm{C}$ with a $12 \mathrm{~h}$ light dark $^{-1}$ photoperiod under constant aeration for a period of 35 days.

Total DNA was extracted from the tissue of the breeders and progenies. Tissues were digested in $100 \mathrm{mM} \mathrm{NaCl}, 20 \mathrm{mM}$ Tris- $\mathrm{HCl}$ (pH 8.0), 100mM EDTA, with a final concentration of $0.05 \%$ SDS and $100 \mu \mathrm{g} \mathrm{mL}^{-1}$ of Proteinase K. After protein digestion, the aqueous phase was extracted once with phenol, phenol/chloroform/isoamyl alcohol and chloroform. DNA was precipitated using ethanol; pellets were washed in $70 \%$ ethanol, dried and re-suspended in TE (0.01M Tris-HCl pH 7.4, 2.5mM EDTA pH 8.0). AFLP analysis of the unique family was performed following the protocol described by VOS et al. (1995), with modifications. Genomic DNA (250ๆg) was digested with $5 \mathrm{U}$ of EcoRI and MseI prior to ligation with restriction site-specific adaptors in $50 \mu \mathrm{L}$ of final volume at $37^{\circ} \mathrm{C}$ for 12 hours, followed by inactivation at $70^{\circ} \mathrm{C}$ for 15 minutes. Next, $10 \mu \mathrm{L}$ of a solution containing $1 \mu \mathrm{g}$ of EcoRI and MseI adapters, 1X T4 DNA ligase buffer and 1U of T4 DNA ligase was added. This reaction was incubated at $20^{\circ} \mathrm{C}$ for three hours and stored at $-20^{\circ} \mathrm{C}$. Pre-amplification was carried out using adaptor-specific primers with a single selective base at the 3' termination. Pre-amplification was performed in $20 \mu \mathrm{L}$ reaction volumes with $2 \mu \mathrm{L}$ of digested and adapted ligated DNA and $25 \eta \mathrm{g}$ of each complementary primer. Amplification conditions were implemented as described by VOS et al. (1995) and the AFLP primer combinations available in the AFLP Analysis System I Kit Gibco (USA) were used. Pre-amplification products were diluted in $100 \mu \mathrm{L}$ of ultra-pure water and used as the template for selective amplification. Selective amplification employed two sets of primers, each containing three selective nucleotides at the 3' termination. For each $10 \mu \mathrm{L}$ of selective reaction, $1 \mu \mathrm{L}$ of diluted pre-amplification product and $25 \eta \mathrm{g}$ of EcoRI-ANN and MseI-CNN primers were used. Reactions were amplified as described by VOS et al. (1995). Selective PCR products were denatured and separated on polyacrylamide gel and visualised by silver staining. For the identification of sexual

Ciência Rural, v.43, n.6, jun, 2013. 
reproductive strategy, 28 AFLP primer combinations were investigated (E - EcoRI; $\mathrm{M}-\mathrm{Mse}$ I and three selective nucleotides): E-ACC / M-CAG; E-ACC/ M-CAT; E-ACC / M-CTA; E-ACC/ M-CTC; E-AAG/ M-CAG; E-AAG / M-CAT; E-AAG / M-CTA; E-AAG / M-CTC; E-ACA / M- CAG; E-ACA / M-CAT; E-ACA / M-CTA; E-ACA / M-CTC; E-ACT/ M-CAG; E-ACT / M-CAT; E-ACT/ M-CTA; E-ACT/ M-CTC; E-AAC / M-CAG; E-AAC/ M-CAT; E-AAC/ M-CTA; E-AAC / M-CTC; E-ACG/M-CAG; E-ACG/M-CAT; E-ACG / M-CTA; E-ACG / M-CTC; E-AGG / M-CAG; E-AGG / M-CAT; E-AGG / M-CTA; E-AGG / M-CTC. All loci were assessed as dominant markers. The distinction between sexual and parthenogenetic reproduction was based on the observation of markers of exclusively paternal origin in the full-sib progenies, since parthenogenetic reproduction produces diploid offspring that are genetically identical to the mother. Maternal and paternal inheritances were counted across progenies by segregating markers, which were tested for deviations from expected 1:1 Mendelian segregation ratios using chi-square $\left(\chi^{2}\right)$ analysis $(\mathrm{P}<0.05)$.

\section{RESULTS AND DISCUSSION}

Out of 16 pairs of nauplii in the first experiment, only one family with 13 progenies emerged. This result is associated to the high level of mortality and non-development of cysts by females. In the second experiment, the small number of females and couples as well as the absence of cysts after 29 days of culture prevented the construction of new families.

Although there are no studies on the environmental factors that influence reproduction in D. brasiliensis, the supply of Chlorella sp. may have provided a suboptimal food condition for reproduction, thereby inducing stress in the second experiment. On the other hand, a large number of pairs consisting of the same sex were observed. Thus, the decision was made to group their members into four male groups composed of four individuals each and three female groups composed of four individuals for daily observation under a microscope. Sex changes were observed over a 72-hour period. Among the four groups of males, two generated a ratio of $1 \delta: 3$, while all males in the remaining groups turned into females (Figure 1). Similarly, the all-female groups either produced proportions of $19: 3 \hat{\jmath}$ or the sexual change of all members into males. In both cases, there were no cysts after the sex change. These results suggest a possible density-dependent control in this population. Further experiments using different densities should be conducted in order to determine the potential density-dependent effect on the sex ratio. Initially, 28 EcoRI and MseI primer combinations were tested in breeders and seven were selected to investigate the Mendelian inheritance pattern in the offspring (Table 1). The chi-square test revealed that these combinations (underlined) demonstrated Mendelian segregation $(1: 1)$ in a total of 40 polymorphic loci (Table 1), among which 14 fragments were of paternal origin (35\%) and 26 were of maternal origin $(65 \%)$, with molecular weight ranging from 95 to $310 \mathrm{bp}(\mathrm{P}<0.05)$.

The distinction between sexual and parthenogenetic reproduction was based on the observation of AFLP-fragments in the full-sib progenies that were of exclusively paternal origin. In Figure 2 (A and B), the presence of marker no 1 for the combination E-ACC / M-CAT and markers numbers 1 and 2 for E-ACC / M-CTA indicates paternal inheritance in the progenies, which confirms the sexual reproduction. Paternal inheritance was also observed in the progenies for the primer combinations E-AAG / M-CAT, E-AAG / M-CTA, E-AAG / M-CTC, E-AAC / M-CTA and E-AAC / M-CTC.

According to CHARNOV (1982), the sex allocation theory predicts equal provision distribution for male and female functions in response to different conditions. This theory also suggests that sex change is favoured when the reproductive value of an individual varies with age or size, and the relationship

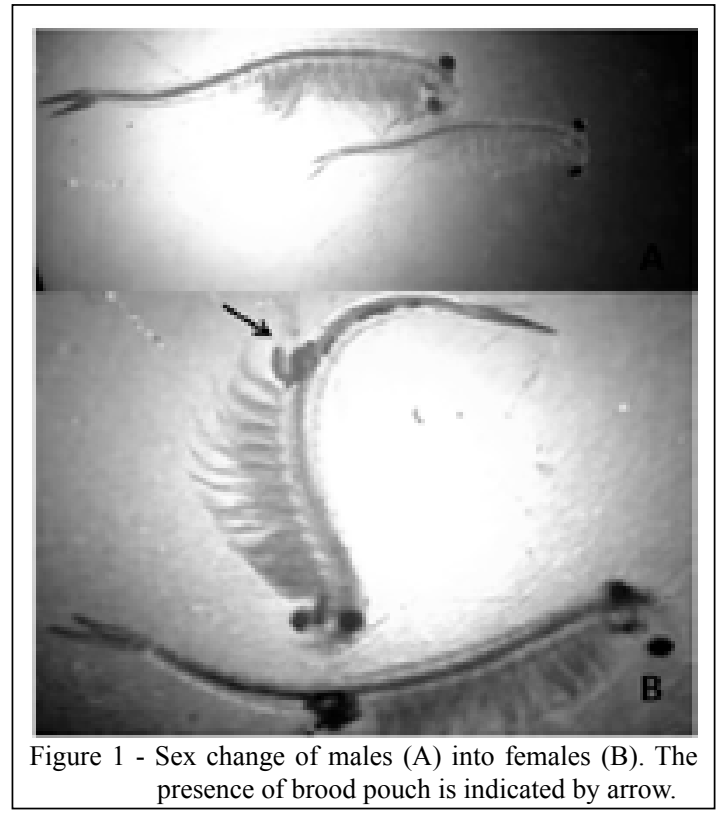

Ciência Rural, v.43, n.6, jun, 2013. 
Table 1 - Number of polymorphic markers scored from AFLP analysis.

\begin{tabular}{|c|c|c|c|c|}
\hline \multirow{2}{*}{ Primers EcoRI (E) } & \multirow[b]{2}{*}{$\mathrm{CAG}$} & \multirow[b]{2}{*}{ CAT } & \multirow[b]{2}{*}{ CTA } & \multirow[b]{2}{*}{ CTC } \\
\hline & & & & \\
\hline $\mathrm{ACC}$ & $12^{\mathrm{a}}$ & 18 & 15 & 0 \\
\hline AAG & 15 & 18 & 14 & 16 \\
\hline $\mathrm{ACA}$ & 0 & 0 & 11 & 10 \\
\hline $\mathrm{ACT}$ & 14 & 9 & 11 & 7 \\
\hline $\mathrm{AAC}$ & 5 & 17 & 19 & 14 \\
\hline $\mathrm{ACG}$ & 0 & 0 & 0 & 0 \\
\hline \multirow[t]{2}{*}{ AGG } & 3 & 2 & 0 & 0 \\
\hline & 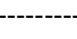 & --Num & marker & ------- \\
\hline $\mathrm{E} / \mathrm{M}$ & CAT & CTA & СТC & Total \\
\hline $\mathrm{ACC}$ & $8^{b}$ & 4 & - & 12 \\
\hline AAG & 5 & 8 & 5 & 18 \\
\hline $\mathrm{AAC}$ & - & 9 & 1 & 10 \\
\hline Total & 13 & 21 & 6 & 40 \\
\hline
\end{tabular}

Primer combinations are denoted by the EcoRI - AXX and MseI - CXX selective nucleotides, respectively;

${ }^{a}$ Number of markers scored per primer combination;

Underlined - AFLP primer combinations selected to investigate the Mendelian inheritance pattern in the full-sibs;

${ }^{\mathrm{b}}$ Total number of polymorphic markers scored.

is different for males and females (ALLSOP \& WEST, 2004), being common in species with separate sexes (BAEZA, 2007).

Rotifers have a life history of parthenogenetic reproduction combined with episodes of sexual reproduction (GILBERT, 1977).
During the parthenogenetic phase, which is the more common reproductive mode, females produce diploid eggs through non-meiotic parthenogenesis that produce daughters that are genetically identical to the mothers. After numerous parthenogenetic generations, sex is induced by environmental factors



Ciência Rural, v.43, n.6, jun, 2013. 
that can predict habitat deterioration (SERRA et al., 2004). In the case of Brachionus plicatilis, sexual reproduction is induced by a density-dependent chemical cue (STELZER \& SNELL, 2003). The genus Artemia comprises a complex of sexual species defined by criteria of reproductive isolation and a large number of parthenogenetic species (VAN STAPPEN, 1996). Sexual species have been described in the Americas, Africa, Europe and Asia, suggesting that this is the most common form of reproduction, while parthenogenetic species are found only in Europe, Asia and Africa (VAN STAPPEN, 1996). The coexistence of parthenogenetic and sexed Artemia species in the same habitat has been reported for the Mediterranean (VAN STAPPEN, 1996).

Overall, sexual species have a large number of progenies and rapid sexual maturation, which is fundamental to population growth and colonisation in new environments where nutrients are limited (VAN STAPPEN, 1996). Moreover, sexual reproduction offers the advantage of producing recombinant types that can make the population better able to adapt to changes in the environment (CROW, 1994).

AFLP proved to be an effective technique in terms of providing a large number of polymorphic fragments without prior knowledge of DNA sequencing of $\boldsymbol{D}$. brasiliensis. The presence of fragments from paternal origin in the progenies of D. brasiliensis confirmed sexual reproduction in this freshwater fairy shrimp. Sexual reproduction offers advantages of recombinant types and rapid sexual maturation, which are important characteristics for the large-scale production of the species. In addition, the observed sex change suggests a sexual plasticity as a response to population sex density, which is advantageous in obtaining individuals of both sexes.

\section{BIOETHICS AND BIOSSECURITY COMMITTEE}

The Animal Ethics Commission of UFRPE ensures that the experiment on the reproductive strategy of branchoneta, Dendrocephalus brasiliensis (Pesta, 1921), is not an issue of ethical analysis, since this species is not classified as sentient animal, and therefore it is not regulated by Law 11.974/2008.

\section{REFERENCES}

ALAM, M.J. et al. Possible use of Moina spp. as a live feed substitute in larval rearing of the freshwater prawn, Macrobrachium rosenbergii (De Man). Aquaculture Fishery Management, v.22, p.531-535, 1991. Available from: < http://onlinelibrary.wiley.com/ doi/10.1111/j.1365-2109.1991.tb00767.x/abstract>. Accessed: Jan. 12, 2008. doi: 10.1111/j.1365-2109.1991.tb00767.x.

ALLSOP, D.J.; WEST, S.A. Sex-ratio evolution in sex changing animals. Evolution, v.58, p.1019-1027, 2004. Available from:
$<$ http://www.zoo.ox.ac.uk/group/west/pdf/Allsop\&West_04. pdf $>$. Accessed: Jan. 14, 2007. doi: 10.1111/j.0014-3820.2004. tb00435.x.

BAEZA, J.A. Male mating opportunities affect sex allocation in a protrandric-simultaneous hermaphroditic shrimp. Behavioral Ecology and Sociobiology, v.61, p.365-370, 2007. Available from: $<$ http://www.springerlink.com/content/h1v45m0720721776/fulltext. pdf $>$. Accessed: Set. 13, 2009. doi: 10.1007/s00265-006-0265-2.

CHARNOV, E.L. The theory of sex allocation. Princeton: Princeton University, 1982. 355p.

COHEN, R.G. Crustacea anostraca. In: LOPRETTO, E.C.; TELL, G. (Eds.). Ecosistema de aguas continentales: metodologias para su estudio. La Plata: SUR, 1995. Tomo II, p.871-895.

CROW, J.F. Advantages of sexual reproduction. Developmental Genetics, v.15, p.205-213, 1994. Available from: <http://www. ncbi.nlm.nih.gov/pubmed/8062455>. Accessed: Sep. 21, 2008. doi: $10.1002 /$ dvg.1020150303.

D'ABRAMO, L.R. et al. Successful culture of larvae of Litopenaeus vannamei fed a microbound formulated diet exclusively from either stage PZ2 or M1 to PL1. Aquaculture, v.261, p.1356-1362, 2006. Available from: <http://www.sciencedirect.com/science/ article/pii/S0044848606007022>. Accessed: Oct. 21, 2007. doi:10.1016/j.aquaculture.2006.09.020.

FAO. The state of world fisheries and aquaculture 2010. Rome, 2010. 197p.

GILBERT, J.J. Mictic-female production in monogonont rotifers. Archives Hydrobiology Beih, v.8, p.142-155, 1977.

IBAMA. Estatística da pesca 2006: grandes regiões e unidades da Federação. Brasília, 2008. 181p.

LAVENS, P.; SORGELOOS, P. The history, present status and prospects of the availability of Artemia cysts for aquaculture. Aquaculture, v.181, p.397-403, 2000. Available from: <http:// www.sciencedirect.com/science/article/pii/S0044848699002331>. Accessed: Dec. 2, 2009. doi: 10.1016/S0044-8486(99)00233-1.

LOVETT, D.L.; FELDER, D.L. Evaluation of the rotifer Brachionus plicatilis as a substitute for Artemia sp in feeding larvas of Macrobrachium rosenbergii. Aquaculture, v.71, p.331338, 1988. doi:10.1016/0044-8486(88)90202-5.

MARTÍN, L. et al. Complete and partial replacement of Artemia nauplii by Moina micrura during early postlarval culture of white shrimp (Litopenaeus schmitti). Aquaculture Nutrition, v.12, p.89-96, 2006. Available from: <http://onlinelibrary.wiley.com/ doi/10.1111/j.1365-2095.2006.00383.x/full>. Accessed: May 3, 2007. doi: 10.1111/j.1365-2095.2006.00383.x.

RABET, N.; THIERY, A. The neotropical genus Dendrocephalus (Crustacea: Anostraca: Thamnocephalidae) in Brazil (South America), with a description of two new species. Journal of Natural History, v.30, p.479-503, 1996. Available from: <http:// dx.doi.org/10.1080/00222939600770261>. Accessed: Nov. 24, 2010. doi: $10.1080 / 00222939600770261$.

SERRA, M. et al. The timing of sex in cyclical parthenogenetic rotifers. In: MOYA, A.; FONT, E. Evolution, from molecules to ecosystems. New York: Oxford University, 2004. p.135-146. 
SORGELOOS, P. et al. State of art in larviculture of fish and shellfish. In: LARVI'9 - FISH AND CRUSTACEAN LARVICULTURE SYMPOSIUM, 15., 1991, Gent, Belgium: European Aquaculture Society, 2008. p.3-5. Accessed: Apr 13, 2008. Online. Available from: <http://www.vliz.be/imisdocs/ publications/135245.pdf>.

STELZER, C.P.; SNELL, T.W. Induction of sexual reproduction in Brachionus plicatilis (Monogononta, Rotifera) by a densitydependent chemical cue. Limnology and Oceanography, v.48, p.939-945, 2003. Available from: <http://www.jstor.org/ stable/3096593>. Accessed: Oct. 20, 2008. doi: 10.2307/3096593.

SUN et al. Diversity and genetic differentiation in Artemia species and populations detected by AFLP markers. International Journal of Salt Lake Research, v.8, p.341-350, 1999. Available from: $<$ http://www.springerlink.com/content/t22340n3814255m2/>. Accessed: Apr. 2, 2012. doi: 10.1023/A:1009023020217.

TRIANTAPHYLLIDIS, G.V. et al. International Study on Artemia. LVII. Morphological and molecular characters suggest conspecificity of all bisexual European and North African Artemia populations. Marine Biology, v.129, p.477-
487, 1997. Available from: <http://www.springerlink.com/ content/2qnaqxde36jvqhcq/>. Accessed: Apr. 3, 2012. doi: $10.1007 / \mathrm{s} 002270050188$.

VAN STAPPEN, G. Artemia: use of cysts. In: LAVENS, P.; SORGELOOS, P. Manual on the production and use of live food for aquaculture. Rome: Food and Agriculture Organization, 1996. p.107-136. (FAO Fisheries Technical Paper n.361).

VOS, P. et al. AFLP: a new technique for DNA fingerprinting. Nucleic Acids Research, v.23, p.4407-4414, 1995. Available from: <http://www.ncbi.nlm.nih.gov/pmc/articles/PMC307397/ pdf/nar00021-0189.pdf $>$. Accessed: Jul. 14, 2009. doi: 10.1093/ nar/23.21.4407.

YFLAAR, B.Z.; OLIVERA, A.G. Utilização de náuplios de "branchoneta" Dendrocephalus brasiliensis (Pesta, 1921) na alimentação de larvas do "camarão cinza" Litopenaeus vannamei (Boone, 1931). Acta Scientiarum, v.25, p.299307, 2003. Available from: <http://periodicos.uem.br/ ojs/index.php/ActaSciBiolSci/article/view/2013/1492>. Accessed: Sept. 23, 2008. doi: 10.4025/actascibiolsci. v25i2.2013.

Ciência Rural, v.43, n.6, jun, 2013. 